\title{
Follow-Up Information
}

National Cancer Institute

\section{Source}

National Cancer Institute. Follow-Up Information. NCI Thesaurus. Code C156846.

Information regarding the follow-up period. 